\title{
A Relationship between Local Government and Civic Groups on Budget Planning in Malang City
}

\author{
Salahudin \\ College of Local Administration (COLA) \\ Universitas Khon Kaen \\ Khon Kaen, Thailand \\ udin.pemerintahan@gmail.com
}

\author{
Vissanu Zumitzavan \\ College of Local Administration (COLA) \\ Universitas Khon Kaen \\ Khon Kaen, Thailand \\ visszu@kku.ac.th
}

\begin{abstract}
Local government, from the executive (regional head and the administration officials) through to the legislative members (parliament), fully controls and directs the major body of budgetary policy. Consequently, budget policy does not incorporate citizens' needs. This research aims to study the relationship between local government and civic groups in the budget planning process of the government of Malang. The findings of this study show that there exists a relationship between local government and civic groups but that the relationship does not represent the principles of democracy (equality, participation, and justice) in the budget planning. These findings contribute to developing budget planning in Malang that establishes a democratic budget policy process that is more responsive to public needs.
\end{abstract}

Keywords-Budget, Policy, Democracy, Government.

\section{INTRODUCTION}

In 1998, Indonesia underwent political reform. At the time, there arose a great awareness of good governance in Indonesia, following on from the multidimensional crisis experienced by the country in 1997. One of the major factors in the crisis was weak public sector governance resulted in corruption, collusion, nepotism, and monopolistic behavior. Consequently, the Indonesian government has changed several regulations, from rules based on an authoritarian system to rules according to the democratic system. However, a democratic system has not been successfully implemented, including in terms of budget planning affairs at the local level.

This issue has been illustrated by the results of research conducted by scholars such as [1], [2], [3], [4], and [5]. They have indicated that local government has dominated civic groups in the budgetary process. Local government's domination in arranging budget and expenditure policy (APBD) was very resilient [3]. The findings of the research indicate that the aspirations of the people, supported by civic groups, do not feature as a part of the policy design, as people are not invited or asked to participate in determining budget policy documents, and civic groups are considered as rivals rather than partners. In line with Jainuri's research, noted that local government dominated budget planning [4]. The local government applies a bureaucratic system during the budget planning, a system which does not provide an opportunity for civic groups to take part. In addition, the research conducted in a local government in China, the budget process is based on a political paradigm in which the involvement of politicians, such as via political parties and parliament, is a part of civic group participation. This means that civic groups in the budget process are represented by politicians [4].

In addition, reveals that the relationship between local government and citizens is dominated by the role of government officials [4]. They arrange the budget established on legal procedures, commonly designed to map the bureaucratic budget. In this context, civic groups have a limited time to become involved in the budget process. Therefore, the final approved budget may be seen as taking the side of the administrators of public affairs. As highlighted by [1] budget planning is underlined by the actions of administration officials. This causes a disproportionate distribution in favor of government over social affairs in budget policy.

Accordance with democratic values, budget planning should be related to citizens, public services, and public goals. Hence, public participation in the budgetary process is an important way to ensure that budget policy is responsive to citizens' needs [1]. They recommend that local officials select a participatory mechanism more deliberatively once the outcomes desired from citizen participation in budgetary decision-making are articulated. The relevant civic groups play a distinctive and vital role in a democratic society [2]. They develop core virtues and values that enable individuals to contribute to society's needs and to help design political institutions adopting public policies supportive of citizen preferences.

A democratic political system requires the active role of civic groups in carrying out their respective functions in shaping and determining public policy, including budgetary policy. As recommended by Huntington [6], the active role of society in the political process is to minimize the political interests of political and bureaucratic elites. Lock [7] believed that through public participation, the problems of life in a society could be solved. In addition, a society would gain knowledge and understanding, develop a sense of social responsibility, and reach new perspectives beyond the boundaries of personal life.

The main role of community organizations is to empower the people so that they have room to advocate their 
aspirations to government [2]. In principle, the core role of civic groups is to empower the people and advocated help of the people to have access and to defend their rights. The contribution of civic groups, including NGOs and nonpolitical organizations, covers advocacy and their performing role as a catalyst in the process of public participation towards good governance in Indonesia. This means increasing the awareness of the executive and the legislature in order for them to open up to public participation or involvement, thus increasing the awareness of citizens regarding their rights and needs, in order for them to participate in the regional regulations drafting process.

The relationship between local government and civic groups in the regional budgetary process (budget planning) should be related to the democratic principles of justice, equality, propriety, and proportionality [8]. Therefore, the democratic values are fostered when public bodies and the implementation of government are open, when opportunities and procedures exist for civic groups to permeate the system, and when responsibility is assured [9].

The Indonesian government has established laws to foster democratic values in government processes and affairs, including budget planning at the local level. Law Number 12 of 2011 on the establishment of legislation aims to ensure participation and transparency in the relationship between the state (including local government) and civic groups in the preparation of public policy (budget planning): "The principle of 'openness' is that the process of establishing legislation, starting from the planning and drafting, through to discussion, are transparent and open, whereby the whole of society (relevant stakeholders) have the widest possible opportunity to provide input into the legislative processes."

Law Number 17 of 2003 on state finances declares, "State finances (including local government finances) should be managed and in order, be subject to laws and regulations, be efficient, economical, effective, transparent, and accountable with regard to fairness and propriety." This position is reaffirmed in Law Number 33 of 2004 on Financial Balances: "Regional finances should be managed in order, be subject to laws and regulations, be efficient, economical, effective, transparent and accountable with regard to fairness, propriety, and benefit to society."

In addition, Law Number 37 of 2014 legislates guidelines for the preparation of the regional budget for 2015 , stating that the preparation of regional budgetary policy should be showing the following principles: "(1) The budgetary policy should be prepared in accordance with the needs of the regional administration; (2) the budgetary policy should be prepared in a timely manner according to the stages and schedules; (3) the preparation of the budget is conducted in a transparent manner, which allows people to find and gain access to information about the budgetary policy; (4) the budget planning should involve the community; (5) the budget should consider fairness and propriety; and (6) the substance of the regional budget should not be contrary to the public interests, higher regulations and other regional regulations." Furthermore, Law Number 14 of 2008 on the public disclosure of information backs the principle of openness in public affairs, including the preparation of the budgetary policy (the budget planning of local governments).

Unfortunately, the laws have not been implemented optimally, proceeding from previous studies such as those conducted by [3], [10], [11], [12], [13], and [14]. The relationship between local government and civic groups in budget planning at the local level in Indonesia does not reflect democratic values. This is due to the lack of socialization on the part of city governments and parliament; the fact that the mechanism at development planning meetings is just ceremonial; and the fact that the awareness of the people, especially middle and lower income groups, is still relatively small. Civic groups' access to active participation is also undermined by local government. Local government, from the executive (regional head and the administration officials) through to the legislative members (parliament), fully controls and directs the major body of budgetary policy. Consequently, budget policy does not incorporate citizens' needs.

The research in the current study was focused on this core issue, divided into three main points. These were: (1) to study the relationship between local government and civic groups in budget planning; (2) to describe its impacts on budget policy in Malang, and to explore the civic groups; (3) to explore efforts to build relationships with local government to design a budget policy to meet citizens' needs. In short, the results of this study indicate that local government dominates budget planning, while civic groups do not participate actively in the budget process.

\section{METHODS}

The qualitative methodology has been applied in this study concerning the issues of dynamic political process in budget planning. It means that actors who involve in budget process having difference perspective and interest on the budget planning. Therefore, to understand the dynamic political process of budget planning, we should be taking part in the field as principles of qualitative method. Qualitative research takes into account that view points and practices in the field are different because of different subjective perspectives and social backgrounds related to them [15]. In line with this argument, we explored the objectives of this study by understanding the background of actors such as elected officials and social activists related to this research. In this case, we have taken place into part of the field during this research. We cannot be doing it in isolate space as quantitative method.

We observed the all stages of budget planning process such as public hearing process (Musrenbang), elected official meeting, and discussion between government officials and members of legislature on approval budget to be legislation on budget policy. By the observation, we got and understood the issues of this study. We interviewed a member of legislature, three government administrators, and forth social activists of civic groups. On other sides, we also used the documents regarding with this research such as laws of local government on budget planning, local government, civic group 
participation, and so on. By the procedures analysis, researchers revealed that there is relationship between local government and civic groups in budget planning.

\section{RESULT AND DISCUSSION}

\section{A. The relationship between local government and civic groups in budget planning}

The main objective of this study is to study the relationship between local government and civic groups in budget planning. The findings of this objective are as follows.

The first finding is that the budget planning (Musrenbang process) is remote from democratic values, namely the participation and equality principles of a democratic system. These democratic values are undermined by several problems in the Musrenbang process. The first problem is that a collusive relationship occurs between the Mayor, the village governments, and the sub-district governments. The second problem is that a collusive relationship occurs between the sub-district governments, village governments, RW staff (the Neighborhood Association) and LPMK staff (Community Empowerment Organization at the Village Level). The third one is that a collusive partnership occurs between the Mayor and pragmatic groups in Malang. The fourth one is that a collusive partnership occurs between pragmatic groups with RW staff and LPMK staff. The fifth one is that civic groups do not have the opportunity to access the Musrenbang process. All these problems are relevant to the state theory discussed earlier that the institution of government has great power in arranging policy. One of a state's characteristics is to dominate the power resources allocated according to their interests [16]. In addition, the dominant political position of elected officials and political elites in participatory budgeting makes it difficult for the civic groups to participate in the stages of the budget planning [17].

The second finding is that manipulative participation takes place in the budget planning for the Musrenbang process. From the local government's perspective, community involvement in the activities of the Musrenbang should be restricted so that the activities can be managed smoothly. Therefore, it is represented by certain groups that are considered to have similar interests, like the MUI (an Islamic Organization under the Indonesian Government) organization, considered to be part of the mass organization movement of Muhammadiyah and Nahdlatul Ulamah (NU). The government view shows that participation in the Musrenbang process is manipulated. Manipulated participation is a form of effort by the government to make public interests match their own interests. These matters have been discussed by [5]. The supposes that while many public officials view a close relationship with citizens as both necessary and desirable, most of them do not actively seek public involvement [5]. These government administrators believe that greater citizen participation increases inefficiency because participation creates delays and increases red tape. The recommends that this participation form be called conventional participation.
Participation in this form is ineffective and conflict, and it happens too late in the process [5].

The third finding is that politicians and government officials dominate the budget policy process. This problem is caused by the collusive action between elected officials, appointed officials, and legislative officials as follows. Firstly, the political communication of the Mayor with the legislative members is mutually respectful. Secondly, the Mayor promotes the interests of business people rather than the interests of society. Thirdly, the team responsible for arranging the budget policy (TAPD) cannot work professionally under the rule of law due to the strong influence of the political interests of the Mayor and of the legislative members (DPRD). Fourthly, the head of SKPDs (Regional Level Work Units) promote political communication with the DPRD to get budgets, instead of promoting the performance of professionalism. Fifthly, the head of SKPDs as budget users prioritizes communication with business before implementing the budget [the private sector]. Sixthly, communication between civic groups and the government is still very limited through seminars, workshops, demonstrations, publications, and public education.

These issues confirm existing research investigating the elected and administrator officials which reveals they have a high level of power and authority in the stages of budget planning. Therefore, they construct a collusive relationship among themselves. In addition, politicians from the political parties take sides of the relationship. Consequently, they devise a budget policy favoring themselves ([3], [13], [10] [14], [11] and [12].

\section{B. The impact of the relationship between local government and civic groups in budget planning}

The secondary objective of this study is to describe the impact of the relationship between local government and civic groups in budget planning. The findings of this objective are as follows.

The impact of the collusive relationship between the government officials and political elites as revealed above is that the structure of the budget policy is not directly known by the people. The budget for the programs seem to be irrationally allocated or not in accordance with society needs and preferences. Elaborate that a collusive relationship among stakeholders is caused directly by deficient society participation in public policy [18]. The higher the political roles of government and politicians in the public policy process, the more likely the process produces public policy that takes the sides of the political interests of politicians and bureaucrats [17].

In addition, [19] recommended that if there is no good collaboration between local government officials and other stakeholders, such as citizens and private groups, this will create a form of local governance not supportive of the need to achieve the goals of government institutions. Therefore, [19] suggests that the public policy process should be based on good collaboration among stakeholders. In this context, he calls this a form of principled engagement occurring over time 
and potentially including different stakeholders at different points, and taking place in either face to face or virtual formats, either crossing organizational networks or in private and public meetings, among others settings.

\section{The Civic Groups' Efforts Build the Relationship with Local Government in Budget Planning}

In addition to the two stated objectives, this research also unravels the relationships between the civic groups and local government in the budget process. This research found that MCW (Malang Corruption Watch) and FMPP (Education Forum Malang) strive to create a collective strength through a movement to build public awareness to enable the public to get involved in the public policy formulation process, including the budget policy process. As suggested by [19], [20], and [8], to build an awareness of collective strength, there is the requirement to put effort into political education for citizens. Political education is considered to be the main vehicle for intellectual and moral reform in order to awaken the collective consciousness of citizens as agents of social change. Furthermore, MCW and FMPP have a wide variety of educational programs that aim to build a collective awareness in order to lobby the Malang government to make and shape policies that favor the people. The forms of political education conducted are seminars, workshops, focus group discussions (FGD), training, and the publication of books.

As suggested by the results of the investigation, as described above, the proposition of the findings of this study are that there is a collusive relationship between politicians, business people, and bureaucrats. The collusive relationships are built by dominating the Musrenbang budget planning process. The relationships are to strengthen the position of dominance of the local government of Malang in deciding budget policy in a way that does not favor the interests of the people of Malang.

As indicated by the findings of this study, revealed above, the relationship between regional government (the executive-legislative) and civic groups in budget planning needs greater efforts towards creating a relationship based on democratic principles, such as participation, equality and justice.

There are some suggestions that would be useful for developing a constructive relationship between the local government and civic groups. Civic groups need to develop critical awareness to participate actively during the establishment of the regional government budget. Some methods to develop public awareness comprise education, seminars, workshops, FGDs, publications, training and democratic schools for the society.

\section{ACKNOWLEDGMENT}

The authors would like to thank Rector of Universitas Muhammadiyah Malang and the Dean of College of Local Administration (COLA) who have financially supported to this research and reviewers for their many helpful comments and suggestions on earlier versions of this paper.

\section{REFERENCES}

[1] A. L. H. A. T. \&. E. C. Franklin. Participatory budgeting in Midwestern states: Democratic connection or citizen disconnection? Public Budgeting \& Finance, vol. 3, no. 29, pp. 52-73, 2009.

[2] D. \&. S. A. Davenport, Civic Associations. Never a Matter, 2003.

[3] Jainuri, State versus civil society: Civil society resistance against to the local government policy in the budget planning, and in the modernization market Dinoyo. Yogyakarta: Litera Book, 2014.

[4] C. Souza, "Participatory budgeting in Brazilian cities: limits and possibilities in building democratic institutions," Environment and Urbanization. vol. 1, no. 13, pp. 159-184., (2001.

[5] C. S. F. K. M. \&. S. B. O. N. King. The question of participation: Toward authentic public participation in public administration. Public Administration Review, pp. 317-326, 1998.

[6] S. P. Hungtinton, The clash of civilizations and the remaking of World Order., New York: NY: Simon Press, 1996.

[7] Lock. J., The two treatises of government. New York: The Federalist Paper Project., 1998.

[8] D. F. Thompson, The democratic citizen, Cambridge: Cambridge University Press, (2010).

[9] C. a. F. A. Ebdon, "Citizen Participation in budgeting theory" Public Administration Review, vol. 3, no. 66, pp. 437-447, 2006.

[10] Salahudin, Korupsi dan pembangunan Daerah, Corruption and Regioal Development., Jogjakarta: Litera Publisher, 2012.

[11] Wijaya, Titik Berat Otonomi pada Daerah Tingkat II. Jakarta: PT Grafindo Persada, 2003.

[12] W. D. Widowati, "Kajian partisipasi masyarakat dalam perencanaan dan penganggaran pembangunan daerah di kabupaten Pati," Universitas Diponegoro, Semarang, 2007.

[13] FITRA, "The performance of local government in managing of public policy," FITRA, Jakarta, 2007.

[14] W. a. Sopanah, "Civic Group participation in the process of preparation of budgets," Brawijaya University, Malang, 2014

[15] U. Flick, An introduction to qualitative research. London: Sage, 2014

[16] M. Manan, People's movement against elites, Yogyakarta: Resist Book Publishers, 2005.

[17] B. He, "Civic engagement through participatory budgeting in China: Three different logics at work" Public Administration and Development, vol. 2, no. 31, pp. 122-133, 2011.

[18] C. O. Jones, Introduction to public policy (public policy)., North Jakarta: Publisher PT Raja Grafindo Persada., 1994

[19] K. N. T. \&. B. S. Emerson, "An integrative framework for collaborative governance" Journal of Public Administration Research and Theory, vol. 1, no. 22, pp. 1-29, 2012.

[20] A. Gaffar, Javanese voters: A case study of an election under a hegemonic party system in Indonesia, Yogyakarta: Gadjah Mada Press, 1997. 